\title{
"Green" Synthesis of Sucrose Octaacetate and Characterization of Its Physicochemical Properties and Antimicrobial Activity ${ }^{\star}$
}

\author{
N. Petkova, ${ }^{a}$ D. Vassilev, ${ }^{b, * *}$ R. Grudeva, ${ }^{a}$ Y. Tumbarski, ${ }^{c}$ \\ I. Vasileva, ${ }^{a}$ M. Koleva, ${ }^{b}$ and P. Denev ${ }^{\mathrm{a}}$ \\ anniversity of Food Technologies, Organic Chemistry Department, \\ Maritza 26 Blvd, Plovdiv, 4002, Bulgaria \\ ${ }^{\mathrm{b}}$ Technical University of Gabrovo, Department "Physics, chemistry \\ \& ecology", Gabrovo, 5300, Bulgaria, 4 H. Dimitar str. \\ 'University of Food Technologies, Department of Microbiology, \\ Maritza 26 Blvd, Plovdiv, 4002, Bulgaria
}

doi: 10.15255/CABEQ.2017.1117

Original scientific paper

Received: March 13, 2017

Accepted: November 6, 2017

\begin{abstract}
Sucrose octaacetate (octa- $O$-acetylsucrose) has been synthesized by esterification of sucrose with acetic anhydride using ultrasound-assisted irradiation. This sucrose ester is a white, water-insoluble substance with a bitter taste. The FT-IR and NMR spectra confirmed acetylation and revealed the hydrophobic incorporation in sucrose molecule. Furthermore, the foamability, foam stability, emulsification and antimicrobial properties of octa- $O$-acetylsucrose were evaluated. Foams and $50 \%$ (oil/water) model emulsions were prepared with $2 \%(\mathrm{w} / \mathrm{w})$ octa- $O$-acetylsucrose. The obtained results demonstrate the formation of emulsions and foams with high stability (50-70\%). The antimicrobial activity of octa- $O$-acetylsucrose was evaluated against seventeen microorganisms (Gram-positive and Gram-negative bacteria, yeasts, and fungi). Octa- $O$-acetylsucrose inhibited the growth of fungi Penicillium sp., Rhizopus sp. and Fusarium moniliforme at $5 \mathrm{mg} \mathrm{cm}^{-3}$, and yeasts Candida albicans at $1 \mathrm{mg} \mathrm{cm}^{-3}$. Inhibition against Gram-positive and Gram-negative bacteria was not observed. The obtained results demonstrate the potential applications of octa- $O$-acetylsucrose as a foaming agent, oil-in-water emulsion stabilizer, and antifungal substance in pharmaceutical and cosmetic preparations.
\end{abstract}

Keywords:

octa- $O$-acetylsucrose, ultrasound-assisted synthesis, foam, antimicrobial properties

\section{Introduction}

Sucrose fatty acid esters have been the cause of increased interest as odorless, nontoxic, and biodegradable nonionic surfactants with a large scale application in the food industry as emulsifiers, anti-fungal and anti-bacterial agents ${ }^{1-5}$, edible coating reagents ${ }^{6}$, solubilizator and detergents in cosmetics and pharmaceuticals ${ }^{7}$, insecticides in agriculture ${ }^{7-9}$ and as bio-plasticizers in engineering ${ }^{5-7}$. In addition, sugar esters are produced from cheap and available renewable raw materials ${ }^{8,9}$. Furthermore, acetylated esters of sucrose are naturally found and derived from several plant species of Nicotiana and Petunia ${ }^{10,11}$.

Sucrose octaacetate is used in many pesticide products and insecticides because of its inert and safety status. It has also been approved by the US

"Presented at the " $4^{\text {th }}$ International Symposium on Environmental Management - Towards Circular Economy (SEM2016), December

7 - 9, Zagreb, Croatia"

${ }^{* *}$ Corresponding author: dvasilev@tugab.bg
Food and Drug Administration as both a direct and indirect food additive, and as a nail-biting and thumb-sucking deterrent in over-the-counter drug products. Sucrose octaacetate may be directly added to food as synthetic flavoring substance, adhesive, packaging material, and adjuvant. Its commercial uses include its addition to lacquers and plastics? This wide application of sucrose acetates requires effective and environmentally friendly methods for their production. The novel approach to the acetylation of sucrose includes lipase-catalyzed esterification of partially acetylated sucrose for the production of biodegradable and biocompatible emulsifiers $^{12}$. Some reports have demonstrated the acetylation of various mono- and disaccharides with $\mathrm{Ac}_{2} \mathrm{O}-\mathrm{NaOAc}$ under microwave and conventional conditions ${ }^{13-15}$. Some encouraging results have been published in relation to the acetylation of lactose by ultrasound-assisted irradiation ${ }^{14}$ and in the modification of some long chain fatty acids sucrose esters ${ }^{4,5,16}$. So far, no detailed results have been published regarding the acetylation of sucrose using the 
environmentally friendly approach of cavitation caused by ultrasonic waves. Moreover, relevant information on the physicochemical properties of sucrose octatacetate is not available in comparison with sucrose esters with long fatty acid chains. Therefore, the aim of the present research is to accelerate the eco-friendly synthesis of sucrose octaacetate by using a "green" method - ultrasound-assisted esterification, and to evaluate its foaming and emulsifying properties for its potential application in agriculture, pharmacy, and cosmetics.

\section{Materials and methods}

\section{Reagents and materials}

D-(+)-Sucrose octaacetate (98\% purity) was purchased from Sigma-Aldrich and used as received. All other reagents and solvents were of analytical grade.

\section{Synthesis of octa-O-acetyl-sucrose}

Sucrose octaacetate was synthesized by the reaction of $10.0 \mathrm{~g}(0.029 \mathrm{~mol})$ sucrose with $30 \mathrm{~cm}^{3}$ $(0.27 \mathrm{~mol})$ acetic anhydride in a two-neck round-bottom flask with $3.0 \mathrm{~g}(0.036 \mathrm{~mol})$ sodium acetate as a catalyst under the following conditions:

- direct heating (over a hot plate, $800 \mathrm{~W}$ ) upon boiling for $60 \mathrm{~min}$ (conventional synthesis);

- ultrasonic irradiation in a VWR ultrasonic bath (VWR, power $30 \mathrm{~W}, 45 \mathrm{kHz}$ ) for $30 \mathrm{~min}$ (US synthesis).

A tube containing anhydrous calcium chloride was fixed on the top of the reflux and a digital thermometer was placed in the flask for temperature monitoring. The reaction mixture was then poured into a $200 \mathrm{~cm}^{3}$ water-ice mixture, stirred vigorously, and left at $18{ }^{\circ} \mathrm{C}$ overnight. Octa- $O$-acetyl-sucrose was precipitated in an excess of cold water as a white solid, filtered, and then washed again with cold water. The acetyl ester was recrystallized from $95 \%$ ethanol and re-precipitated with water, and then dried in a vacuum-oven to constant weight. The sucrose octaacetate was characterized by physicochemical methods.

\section{Methods for characterization}

Melting point and water activity Sample melting point was determined on an electro-thermal melting point apparatus BÜCHI 510 (Germany) in a capillary glass tube. Here, water activity $\left(a_{\mathrm{w}}\right)$ was measured with a water activity meter (AquaLab Pre, Labcell Ltd., UK).

Thin layer chromatography (TLC) The TLC analysis was performed on silica gel Kieselgel 60
$\mathrm{F}_{254}$ plates (Merck, Germany) with toluene/ethyl acetate/methanol/water 10:5:4.5:0.2 (v/v/v/v) as an eluent. Spots were detected by spraying the plates with $10 \%(\mathrm{v} / \mathrm{v}) \mathrm{H}_{2} \mathrm{SO}_{4}$ in methanol, and visualized by heating in an oven at $120{ }^{\circ} \mathrm{C}$ for $5 \mathrm{~min}^{9}$.

FT-IR spectroscopy The infrared spectra of the samples were recorded on a Nicolet FT-IR Avatar Nicolet (Thermo Science, USA) spectrometer using $\mathrm{KBr}$ pellets, and the absorption was reported in wavenumbers $\left(\mathrm{cm}^{-1}\right)$ in the frequency range of 4000-400 $\mathrm{cm}^{-1}$. Each spectrum was recorded after 120 scans.

NMR analysis Similarly, the ${ }^{1} \mathrm{H}$ and ${ }^{13} \mathrm{C}$ NMR spectra of the sucrose octaacetate were recorded on a Bruker Advance III $500 \mathrm{MHz}$ spectrometer using $\mathrm{CDCl}_{3}$ as a solvent. ${ }^{13} \mathrm{C}$ NMR spectrum was recorded operating at $151 \mathrm{MHz}$. All chemical shifts were reported in ppm with reference to TMS.

Hydrophilic-lipophilic balance (HLB) calculation Sucrose octaacetate HLB values were calculated by Griffin's methods ${ }^{17}$.

Foamability and foaming stability Foamability and foaming stability of the sucrose octaacetate were evaluated by the previously described method $^{2}$ with slight modifications ${ }^{18}$. In brief, the aqueous dispersion of sucrose octaacetate $0.2 \mathrm{~g} \mathrm{dm}^{-3}$ was placed in $50 \mathrm{~cm}^{3}$ in stoppered graduated cylinders and the height of each solution $\left(H_{0}, \mathrm{~cm}\right)$ was measured. The solution was then shaken for $1 \mathrm{~min}$, and the foam height $\left(H_{2}, \mathrm{~cm}\right)$ and the total height $\left(H_{1}\right.$, $\mathrm{cm})$ were determined immediately. Following a stay for $1,5,10,15,20,25,30 \mathrm{~min}$ and $60 \mathrm{~min}$, the foam height $\left(H_{3}, \mathrm{~cm}\right)$ was recorded at $25^{\circ} \mathrm{C}$. All the experiments were performed in triplicate. Foamability and foaming stability were calculated using the following equations:

$$
\begin{aligned}
& \text { Foamability }(\%)=\left[\left(H_{1}-H_{0}\right) / H_{0}\right] \cdot 100 \\
& \text { Foaming stability }(\%)=\left(H_{3} / H_{2}\right) \cdot 100
\end{aligned}
$$

Characterization of 50/50 $\mathrm{O} / \mathrm{W}$ model emulsions with sucrose octaacetate Twenty-milliliter solution $(2.0 \mathrm{wt} \%)$ was homogenized with $20 \mathrm{~cm}^{3}$ sunflower oil for $5 \mathrm{~min}$ at $1000 \mathrm{rpm}$ on a homogenizer (Ultra Turrax IKA T18 Basic, Germany). Emulsion stability of the prepared 50/50 oil-in-water $(\mathrm{O} / \mathrm{W})$ emulsions was evaluated by centrifugation and determination of separated phases. Ten $\mathrm{cm}^{3}$ of each emulsion were placed in graduated centrifuge tubes, and centrifuged at $314 \mathrm{rad} \mathrm{s}^{-1}$ for 15 $\min ^{19}$. Emulsion stability $(S)$ was defined by the formula (3):

$$
S(\%)=\left[\left(V_{\mathrm{o}}-V\right) / V_{\mathrm{o}}\right] \cdot 100
$$

where: $V_{\mathrm{o}}$-volume of the emulsion $\mathrm{cm}^{3} ; V$-volume of the separated oil phase, $\mathrm{cm}^{3}{ }^{18}$. 
It was also evaluated by a temperature test. Five $\mathrm{cm}^{3}$ of each emulsion was placed in test tubes, which were stored at four different temperatures: $-18{ }^{\circ} \mathrm{C}$ (frozen); $4{ }^{\circ} \mathrm{C}$ (refrigerator temperature); $25{ }^{\circ} \mathrm{C}$ (room temperature), and $50{ }^{\circ} \mathrm{C}$ (water bath or thermostat) for 24 hours and 48 hours ${ }^{19}$.

Turbidity measurement of the emulsion stability The dispersion of the emulsions was evaluated by spectrophotometric measuring of turbidity (TU, $\%$ ) at a wavelength of $540 \mathrm{~nm}$ (Camspec-M 107 spectrophotometer, UK) ${ }^{18}$.

Antimicrobial activity Antimicrobial activity tests were performed under the following conditions:

- Test microorganisms. Three Gram-positive bacteria (Bacillus subtilis ATCC6633, Bacillus subtilis 46/H1, Bacillus methylotrophicus BM47), three Gram-negative bacteria (Escherichia coli ATCC8739, Salmonella sp. - clinical isolate, Salmonella abony), yeasts (Candida albicans - clinical isolate, Candida tropicalis, Saccharomyces cerevisiae), and fungi (Aspergillus niger, Aspergillus awamori, Aspergillus oryzae, Fusarium oxysporum, Fusarium moniliforme, Beauveria bassiana, Penicillium sp., Rhizopus sp.) from the collection of the Department of Microbiology at the University of Food Technologies, Plovdiv, Bulgaria, were selected for the antimicrobial test. The concentration of the viable cells and spores in the suspensions for inoculation was adjusted to $1.0 \cdot 10^{5} \mathrm{CFU} \mathrm{cm}^{-3}$ (for fungal

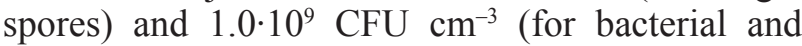
yeast cells).

- Culture media. LBG-agar medium (10 g tryptone, $5 \mathrm{~g}$ yeast extract, $10 \mathrm{~g} \mathrm{NaCl}$ and $10 \mathrm{~g}$ glucose and $15 \mathrm{~g}$ agar per $1 \mathrm{dm}^{3}$ of deionized water) with $\mathrm{pH} 7.5$ for the cultivation of Gram-positive, Gram-negative and yeasts was used. Malt extract agar medium (20 g malt extract, $20 \mathrm{~g}$ dextrose, $6 \mathrm{~g}$ peptone and $15 \mathrm{~g}$ agar per $1 \mathrm{dm}^{3}$ of deionized water) with $\mathrm{pH} 5.5$ for the cultivation of the fungi was used. Both agar media were autoclaved for $20 \mathrm{~min}$ at $121^{\circ} \mathrm{C}^{20}$.

- Antimicrobial assay. Aqueous methanol (80 $\%$ ) was used as a solvent to prepare desired solutions $\left(1,5\right.$ and $\left.10 \mathrm{mg} \mathrm{cm}^{-3}\right)$ of octa- $O$-acetylsucrose
US (synthesized by ultrasound-assisted irradiation). For determination of antimicrobial activity, the disc diffusion method in LBG-agar medium was implemented with slight modification ${ }^{15}$.

The melted LBG-agar medium was poured into Petri dishes $(d=10 \mathrm{~cm})$ and after its hardening, the Petri dishes were inoculated with suspensions of the test microorganisms ${ }^{21}$. Sterile paper discs with a diameter of $6 \mathrm{~mm}$ were then placed on the surface of the agar medium, and $6 \mu \mathrm{L}$ from octa- $O$-acetylsucrose solutions in two replicates were pipetted on the discs. As controls, $80 \%$ methanol and the antibiotic Nystatin $\left(40 \mu \mathrm{g} \mathrm{cm}^{-3}\right)$ were used.

Inoculated Petri dishes were cultivated for 24 hours at $37^{\circ} \mathrm{C}$ for Escherichia coli, Salmonella sp., Salmonella abony, Candida albicans and $30{ }^{\circ} \mathrm{C}$ for Candida tropicalis, Saccharomyces cerevisiae, Bacillus subtilis, Bacillus methylotrophicus, Aspergillus niger, Aspergillus awamori, Aspergillus oryzae, Fusarium oxysporum, Fusarium moniliforme, Beauveria bassiana, Penicillium sp. and Rhizopus sp. Antimicrobial activity was determined by measuring the diameter of the inhibition zones around the $\operatorname{discs}^{20,21}$.

\section{Results and discussion}

\section{Synthesis and characterization of sucrose acetates}

The octa- $O$-acetyl-sucrose was obtained after the esterification of the sucrose with an excess of acetic anhydride with sodium acetate as a catalyst. Ultrasound-assisted acetylation of sucrose is illustrated in Fig. 1, and as a result of this process, the eight free hydroxyl groups are esterified to acetyl esters.

Octa-O-acetyl-sucrose presented white odorless powder with a bitter taste, soluble in acetone, DMSO, $95 \%$ ethanol, methanol and insoluble in water. Therefore, its hydrophobic character was due to the substitution of free $\mathrm{OH}$ groups with acetyl residues. The ultrasound-assisted acetylation of sucrose reduces the time for synthesis to $30 \mathrm{~min}$, and
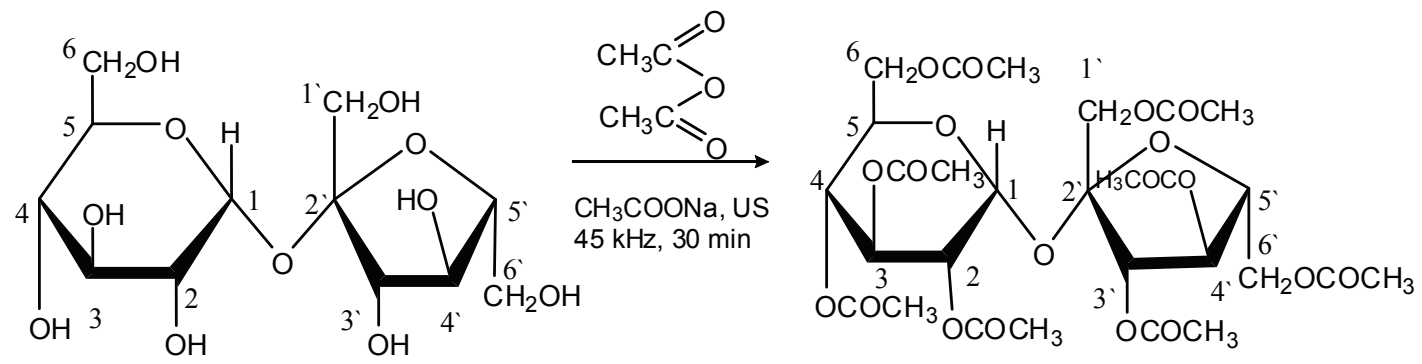

Fig. 1 - Ultrasonic synthesis of sucrose acetates 
Table 1 -Characterization of sucrose and sucrose acetates

\begin{tabular}{l|c|c|c}
\hline \multicolumn{1}{c|}{ Sample } & $\begin{array}{c}\text { Yield, } \\
\%\end{array}$ & $\begin{array}{c}\text { Melting point, } \\
{ }^{\circ} \mathrm{C}\end{array}$ & $a_{\mathrm{w}}($ mean $\pm \mathrm{SD})$ \\
\hline Sucrose & - & $186-188$ & $0.780 \pm 0.002$ \\
$\begin{array}{l}\text { Octa- } O \text {-acetylsucrose } \\
\text { Sigma) }\end{array}$ & - & $81-83$ & $0.406 \pm 0.002$ \\
$\begin{array}{l}\text { Octa- } O \text {-acetylsucrose } \\
\text { conventional }\end{array}$ & 62 & $82-84$ & $0.408 \pm 0.002$ \\
$\begin{array}{l}\text { Octa- } O \text {-acetylsucrose } \\
\text { US }\end{array}$ & 78 & $82-83$ & $0.405 \pm 0.003$ \\
\hline
\end{tabular}

energy, as the reaction was conducted at a lower temperature and $30 \mathrm{~W}$ power in comparison to the conventional heating for esterification. Higher yield was obtained by ultrasound-assisted esterification of sucrose with acetic anhydride at a mild temperature of $45^{\circ} \mathrm{C}$ (Table 1$)$.

The octa- $O$-acetylsucrose obtained under boiling temperature appeared as white solids with dark-yellow hues and caramel-like odor even after the recrystallization with ethanol. Because of degradation products formed during the high temperature of the esterification process, the yield of sucrose octaacetate was lower than the ultrasound-assisted synthesis (Table 1). An additional separation was needed because lower esters as mono-, di- and triacetate of sucrose were formed under ultrasonic irradiation (Fig. 1). These esters transformed the white solids in a semi-liquid substance at room temperature. The water activity of the synthesized esters was lower than the initial sucrose. The $a_{\mathrm{w}}$ values of the sucrose octaacetate were in the range of 0.390 to 0.406 , which were in accordance with our previous reports on alkylated carbohydrates ${ }^{5}$.

Octa- $O$-acetylsucrose (78 \% yield) is a crystalline solid, mp. $87-88{ }^{\circ} \mathrm{C}$ (reported ${ }^{11,15} \mathrm{mp}$. 88-89
${ }^{\circ} \mathrm{C}$ ). $\mathrm{R}_{f}=0.9$ (toluene/ethyl acetate/methanol/water $=10: 5: 4.5: 0.2)$. FT-IR (KBr): 1751, $1736 \mathrm{~cm}^{-1}$ $(\mathrm{C}=\mathrm{O})$.

${ }^{1} \mathrm{H}$ NMR (500 MHz, $\left.\mathrm{CDCl}_{3}\right): 5.61(1 \mathrm{H}, \mathrm{d}, J=$ $3.5 \mathrm{~Hz}, \mathrm{H}-1$ from glucose residue), $5.38(1 \mathrm{H}, \mathrm{d}, J=$ $\left.5.5 \mathrm{~Hz},-\mathrm{H} 1^{\prime}\right), 5.36\left(1 \mathrm{H}, \mathrm{d}, J=5.7 \mathrm{~Hz}, \mathrm{H}-3^{\prime}\right), 5.31$, 5.30, 5.29 (1H, t, $\left.J=5.8 \mathrm{~Hz}, \mathrm{H}-4^{\prime}\right), 5.02(1 \mathrm{H}, \mathrm{t}, J=$ $11.0 \mathrm{~Hz}, \mathrm{H}-4), 4.94(1 \mathrm{H}, \mathrm{dd}, J=10.0$ and $3.8 \mathrm{~Hz}$, H6 ), 4.29-4.21, 4.19, 4.17, 4.16, 4.15, 4.13, 4.06 $\left(8 \mathrm{H}, 2 \times \mathrm{m}, \mathrm{H}-5, \mathrm{H}-6, \mathrm{H}-1^{\prime}, \mathrm{H}-5^{\prime}\right.$ and H-6), $2.12(3 \mathrm{H}$, $\left.\mathrm{s},-\mathrm{OCOCH}_{3}\right), 2.04(6 \mathrm{H}, \mathrm{s}), 2.03(3 \mathrm{H}, \mathrm{s}), 2.02(6 \mathrm{H}$, s) (from 2.04-2.02 total $\left.15 \mathrm{H}, \mathrm{s}, 5 \times-\mathrm{OCOCH}_{3}\right), 1.96$ $\left(3 \mathrm{H}, \mathrm{s},-\mathrm{OCOCH}_{3}\right), 1.91\left(3 \mathrm{H}, \mathrm{s},-\mathrm{OCOCH}_{3}\right) \mathrm{ppm}$.

${ }^{13} \mathrm{C}$ NMR (126 MHz, $\left.\mathrm{CDCl}_{3}\right)$ 170.72, 170.50, $170.13,170.11,170.05,169.91,169.68,169.53$ $\left(8 \times \mathrm{CH}_{3} \mathrm{CO}\right), 104.00$ (C-2'), 89.9 (C-1), 79.11(C-5'), 75.68, 74.97, 70.27, 69.62, 68.49, 68.19 (C-2, C-3, C-4, C-5, C-3', C-4'), 63.65, 62.87, 61.74, (C-6, $\left.\mathrm{C}-6^{\prime}, \mathrm{C}-1^{\prime}\right), 20.72-20.56\left(8 \times \mathrm{CH}_{3} \mathrm{CO}\right) \mathrm{ppm}$.

Sucrose and its octaacetate esters were dissolved in $95 \%$ ethanol and analyzed by thin-layer chromatography (TLC). The spots of synthesized esters (3) coincided with $\mathrm{R}_{f}$ values of commercial standard octa- $O$-acetylsucrose (Sigma) (2), whereas $\mathrm{R}_{f}$ values obtained for all sucrose octaacetate were found to be 0.9 , therefore, it was possible to consider that the desired sugar esters had been obtained.

Furthermore, the sucrose- $O$-acetyl esters were analyzed by infrared spectroscopy (Fig. 2), and the obtained spectra showed strong new bands at $1751 \mathrm{~cm}^{-1}$ attributed to stretching of $\mathrm{C}=\mathrm{O}$ group, $1383 \mathrm{~cm}^{-1}$ $\left(\delta_{\mathrm{C}-\mathrm{H}}\right)$ and $1236 \mathrm{~cm}^{-1}\left(v_{\mathrm{C}-\mathrm{O}}\right)$ were due to the presence of ester bonds of acetyl residues linked to sucrose moiety. Moreover, the strong bands at $3392 \mathrm{~cm}^{-1}$ in the sucrose spectrum, characteristic for the $\mathrm{OH}$ stretching vibration, disappeared in the sucrose octaacetate spectrum as a result of a successful substitution. Additionally, the presence of bands at $910 \mathrm{~cm}^{-1}$

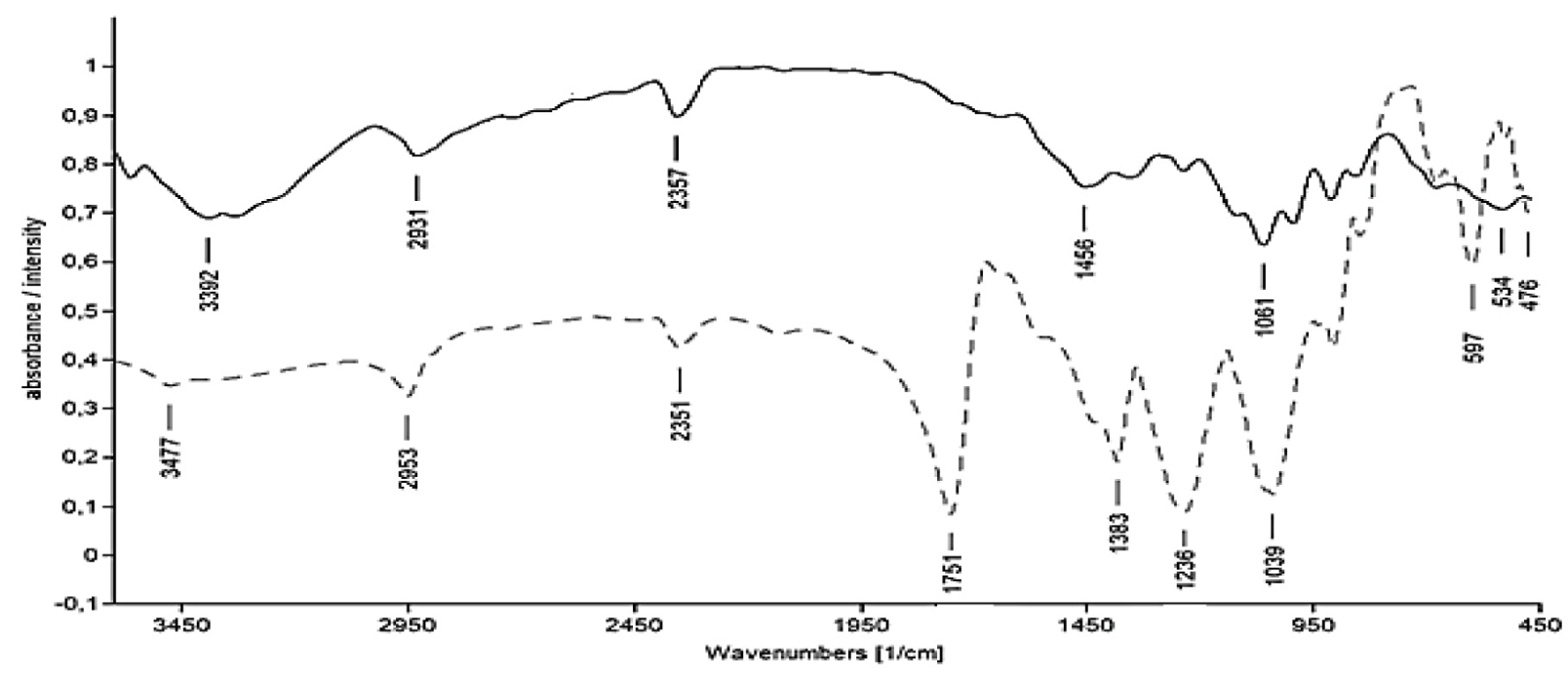

Fig. 2 - FT-IR spectra of sucrose (-) and octa-O-acetylsucrose (- -) synthesized by ultrasonic irradiation 


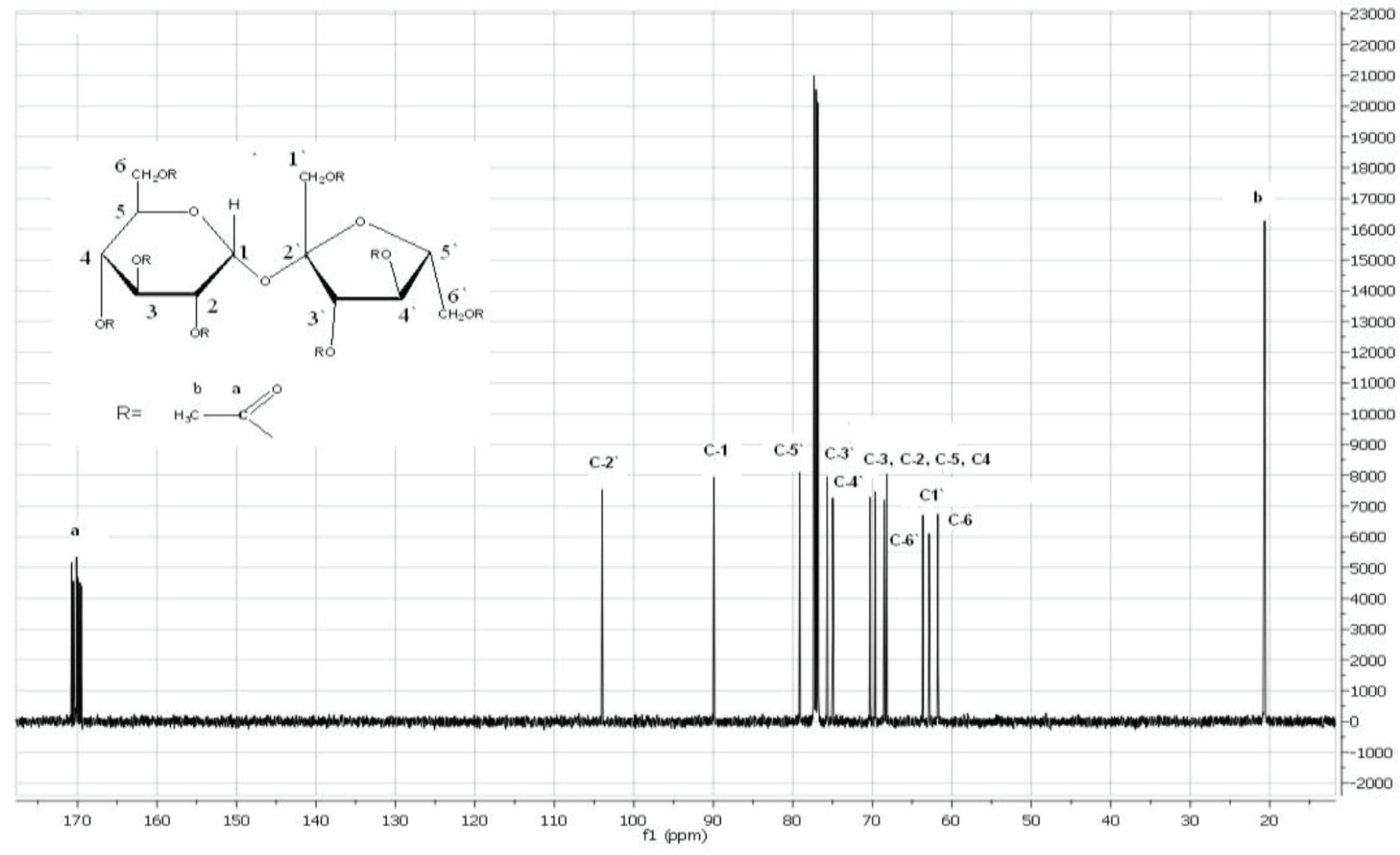

Fig. $\left.3-{ }^{13} \mathrm{C} \mathrm{NMR} \mathrm{spectrum} \mathrm{(126} \mathrm{MHz,} \mathrm{CDCl}_{3}\right)$ of octa-O-acetylsucrose synthesized by ultrasound-assisted irradiation

in both spectra proved that the resulting ester contained $\alpha$-D-Glc $p$ residue in chain; bond stretching of sucrose.

In the ${ }^{1} \mathrm{H}$ NMR spectrum, twenty-four protons resonated at $\delta 2.12(3 \mathrm{H}, \mathrm{s}), 2.04(6 \mathrm{H}, \mathrm{s}), 2.03(3 \mathrm{H}$, s), $2.02(6 \mathrm{H}, \mathrm{s}), 1.96(3 \mathrm{H}, \mathrm{s})$ and $1.91(3 \mathrm{H}, \mathrm{s})$ corresponding to the eight acetyloxy groups. The structure of sucrose residue could also be observed with characteristic chemical shifts for carbohydrates in the range of $3.39 \sim 5.38 \mathrm{ppm}$ (protons of glucose part) and $3.58 \sim 4.39 \mathrm{ppm}$ (protons of fructose residue). An isolated doublet around $5.3 \mathrm{ppm}$ is due to anomeric proton from glucose unit $(1 \mathrm{H}-\mathrm{Cl} c p)$. The structure of $1^{\prime}, 2,3,3^{\prime}, 4,4^{\prime}, 6,6^{\prime}$-octa- $O$-acetylsucrose was additionally confirmed by the ${ }^{13} \mathrm{C}$ NMR spectrum (Fig. 3), where eight chemical shifts, characteristic for acetyl carbonyl, had clearly appeared at $170.72,170.50,170.13,170.11,170.05,169.91$, 169.68 and $169.53 \mathrm{ppm}$. In addition, all the methyl carbons from the acetyl residue appeared at 20.5 ppm $\left(8 \times \mathrm{COCH}_{3}\right)$. Carbon atoms of the sucrose moiety were found in the range of $61.32 \sim 103.88 \mathrm{ppm}$. Data obtained on the NMR spectra of the sucrose octaacetate were in accordance with the previous report on the chemically enzymatic and naturally isolated, chemically and enzymatically modified sucrose octaacetates ${ }^{11,12,15}$. Therefore, the esters synthesized by conventional and ultrasound-assisted methods corresponded to the octa- $O$-acetylsucrose.

\section{Foaming and emulsifying properties}

On the basis of the calculated HLB values of the octa- $O$-acetylsucrose (HLB 7-8), it was decided to check their foaming and emulsifying properties.

\section{Foaming properties}

Foaming properties of octa- $O$-acetylsucrose (standard and synthesized by ultrasound-assisted esterification) were evaluated by the foaming capacity (FC) and foam stability (FS). These two parameters were important for the evaluation of forming foams ${ }^{22}$. Changes in the foaming properties of the sucrose octaacetate in the initial and final state after $60 \mathrm{~min}$ are presented (Fig. 4).

Foaming stability was influenced by the standing time. It was shown that foam stability of octa- $O$-acetylsucrose slightly decreased during standing time from $1 \mathrm{~min}$ to $60 \mathrm{~min}$. Likewise, it was clearly observed that foam height slowly began to decrease immediately after foaming formation. Foam capacity of octa- $O$-acetylsucrose could be measured at a concentration of $0.2 \mathrm{~g} \mathrm{dm}^{-3}$ for only 30 min, which did not exceed $52-55 \%$. No significant differences were observed between standard and ultrasound-assisted synthesized sucrose octaacetate. Foam stability of the $O$-acetyl sucrose was close to the previous report on the lactose lauryl esters ${ }^{2}$. The sucrose octaacetate was the perfect candi- 


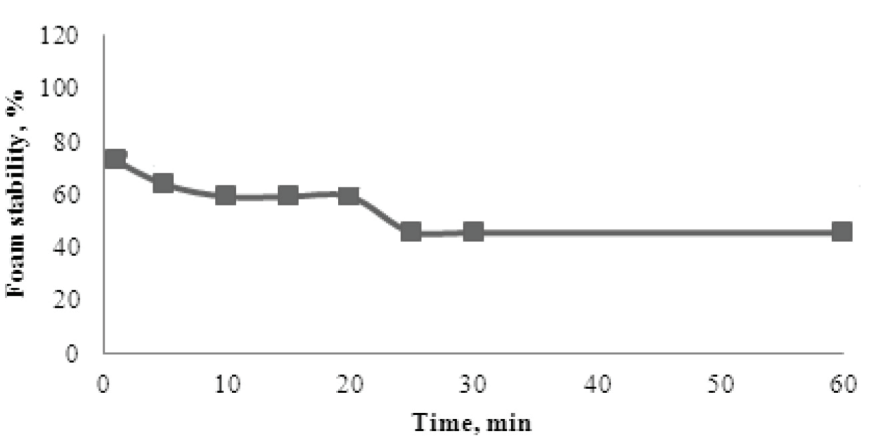

Fig. 4 - Foam stability of octa-O-acetylsucrose from ultrasound-assisted synthesis

date for an ideal foam-forming agent because it is non-toxic and able to produce abundant, thick, and stable foam at a low concentration of $0.2 \mathrm{~g} \mathrm{dm}^{-3}$.

The emulsifying properties of the sucrose octaacetates were studied in model systems with $2.0 \%$ (wt) relative to the aqueous medium and $50 \%$ oil phase of the emulsion of the oil/water type. From the obtained results, it was found that both sucrose octaacetates were characterized with closed dispersity $54-60 \%$ (Table 2 ). The most stable $\mathrm{O} / \mathrm{W}$ emulsions were formed with $2 \%$ synthetic sucrose octaacetates.

The impact of thermal processing and freezing on the emulsion stability was also evaluated (Table $3)$. All prepared emulsions were unstable at $-18{ }^{\circ} \mathrm{C}$ and $50{ }^{\circ} \mathrm{C}$ for $24 \mathrm{~h}$, respectively. More stable were

Tab1e 2 - Emulsion stability (in \% separated phase) of 50/50 $\mathrm{O} / \mathrm{W}$ model emulsion

\begin{tabular}{l|c|c|c|c}
\hline \multirow{2}{*}{$\begin{array}{l}\text { Ester concentration, } 2.0 \% \\
(\mathrm{wt}) \text { of oil phase }\end{array}$} & \multicolumn{3}{|c|}{ Separated phase, $\% \pm 0.1$} & \multirow{2}{*}{$T, \%$} \\
\cline { 2 - 5 } & Oil & Water & Emulsion & \\
\hline $\begin{array}{l}\text { Octa- } O \text {-acetylsucrose } \\
\text { - standard (Sigma) }\end{array}$ & 65.7 & 32.3 & 0.0 & 54.1 \\
Octa- $O$-acetylsucrose - US & 26.1 & 69.6 & 4.3 & 60.0 \\
\hline
\end{tabular}

Table 3 -Temperature test for emulsion stability (\%) of 50/50 O/W emulsions prepared with $2.0 \%$ (wt) octa-O-acetyl-sucrose

\begin{tabular}{l|c|c|c|c}
\hline \multicolumn{1}{c|}{ Substance } & $\begin{array}{c}\text { Temperature, } \\
{ }^{\circ} \mathrm{C}\end{array}$ & Water & $\begin{array}{c}\mathrm{O} / \mathrm{W} \\
\text { Emulsion }\end{array}$ & Oil \\
\hline & -18 & 30 & 0 & 70 \\
Octa- $O$-acetylsucrose & 4 & 32 & 62 & 6 \\
- standard & 25 & 32 & 60 & 8 \\
(Sigma-Aldrich) & 50 & 38 & 0 & 62 \\
\hline & -18 & 38 & 52 & 10 \\
& 4 & 28 & 68 & 4 \\
Octa-O-acetylsucrose & 25 & 10 & 84 & 6 \\
- US & 50 & 41 & 20 & 39 \\
\hline
\end{tabular}

emulsions stored at $4{ }^{\circ} \mathrm{C}$ followed by $20^{\circ} \mathrm{C}$. More detailed studies are required for the emulsion stability of the sucrose acetate.

\section{Antimicrobial properties of octa-O-acetylsucrose}

Many studies deal with antimicrobial activity of sucrose esters with fatty acids. In general, monoesters were more active than diesters, but in some cases, polyesters also demonstrate good activi$t^{2,3,5,21}$. To the best of our knowledge, the octaacetate esters of sucrose are little investigated for antimicrobial activity. In this study, we investigate the effect of octaacetyl ester of sucrose against the growth of seventeen microorganisms (Gram-positive and Gram-negative bacteria, yeasts, and fungi) with the results being summarized in Table 4 .

The antimicrobial studies revealed that octa- $O$-acetylsucrose was more active against fungi and yeasts (Table 4). Applied solvent $\left(80 \% \mathrm{CH}_{3} \mathrm{OH}\right)$ did not cause antimicrobial activity. It was clearly observed that sucrose acetate esters inhibited the mycelial growth of fungi Aspergillus oryzac, Penicillium sp., Rhizopus sp. and Fusarium moniliforme and yeast Candida albicans at a concentration of 1,5 and $10 \mathrm{mg} \mathrm{cm}^{-3}$. Octa- $O$-acetylsucrose showed moderate antimicrobial activity against Penicillium sp. and Rhizopus sp. comparable with the activity of control Nystatin. In contrast, the growth of the fungi Aspergillus niger, Aspergillus awamori, Fusarium oxysporum and Beauveria bassiana remained unaffected. This is the first report about screening of the antimicrobial activity of octa- $O$-acetylsucrose against fungi Beauveria bassiana, Penicillium sp., Rhizopus sp. and Fusarium moniliforme, yeasts Candida tropicalis, Candida albicans, Saccharomyces cerevisiae, and bacteria (Salmonella abony and Bacillus methylotrophicus). The substance was active against yeasts Candida albicans at concentration 1 and $5 \mathrm{mg} \mathrm{cm}^{-3}$. No inhibition against Gram-positive and Gram-negative bacteria was detected. Matin et al. ${ }^{15}$ also reported that octa- $O$-acetylsucrose in concentration $50 \mu \mathrm{g}(\mathrm{dw}) \mathrm{cm}^{-3}$ did not inhibit the growth of Bacillus subtilis, Escherichia coli, Pseudomonas aeruginosa and Aspergillus niger, Fusarium equiseti in concentration $100 \mu \mathrm{g}(\mathrm{dw})$ $\mathrm{cm}^{-3}$, respectively. Similarly to sucrose myristate and sucrose palmitate, glycerol acetates ${ }^{23,24}$, octa- $O$ acetylsucrose did not inhibit the growth of food born pathogen $B$. subtilis. Another important finding is that octa- $O$-acetylsucrose stimulates the growth of Bacillus methylotrophicus, therefore, this substance is a substrate for its growth. Bacillus methylotrophicus bacteria are with a key role in control of corn stalk rot caused by Fusarium graminearum $^{25}$. Numerous specialized methylotrophs have been described, including a great diversity of methanotrophs - most of them are methane con- 
Table 4 -Antimicrobial activity of octa-O-acetylsucrose expressed as diameter of zones of inhibition in $\mathrm{mm}\left(d_{\text {disc }}=6 \mathrm{~mm}\right)$

\begin{tabular}{|c|c|c|c|c|c|c|c|c|c|c|}
\hline \multirow{4}{*}{ Test microorganisms } & \multicolumn{10}{|c|}{ Diameter of inhibition zones, $\mathrm{mm}$} \\
\hline & \multicolumn{6}{|c|}{ Octa- $O$-acetylsucrose } & \multicolumn{4}{|c|}{ Controls } \\
\hline & \multicolumn{2}{|c|}{$1 \mathrm{mg} \mathrm{cm}^{-3}$} & \multicolumn{2}{|c|}{$5 \mathrm{mg} \mathrm{cm}^{-3}$} & \multicolumn{2}{|c|}{$10 \mathrm{mg} \mathrm{cm}^{-3}$} & \multicolumn{2}{|c|}{$80 \% \mathrm{CH}_{3} \mathrm{OH}$} & \multicolumn{2}{|c|}{ Nystatin } \\
\hline & $24 \mathrm{~h}$ & $48 \mathrm{~h}$ & $24 \mathrm{~h}$ & $48 \mathrm{~h}$ & $24 \mathrm{~h}$ & $48 \mathrm{~h}$ & $24 \mathrm{~h}$ & $48 \mathrm{~h}$ & $24 \mathrm{~h}$ & $48 \mathrm{~h}$ \\
\hline Aspergillus niger & - & - & - & - & - & - & - & - & - & - \\
\hline Aspergillus awamori & - & - & - & - & - & - & - & - & - & - \\
\hline Aspergillus oryzae & $8 *$ & - & 8 & - & 8 & - & - & - & 8 & - \\
\hline Fusarium oxysporum & - & - & - & - & - & - & - & - & - & - \\
\hline Fusarium moniliforme & 8 & - & $9 *$ & 9 & 9 & 9 & - & - & - & - \\
\hline Beauveria bassiana & - & - & - & - & - & - & - & - & - & - \\
\hline Penicillium sp. & 8 & - & $10 * *$ & 10 & 8 & - & - & - & 8 & - \\
\hline Rhizopus sp. & - & - & 8 & - & 8 & - & - & - & 9 & - \\
\hline Candida tropicalis & - & - & - & - & - & - & - & - & - & - \\
\hline Candida albicans & 8 & 8 & 8 & 8 & - & - & - & - & - & - \\
\hline Saccharomyces cerevisiae & - & - & - & - & - & - & - & - & - & - \\
\hline Salmonella sp. & - & - & - & - & - & - & - & - & $\mathrm{N} / \mathrm{A}$ & $\mathrm{N} / \mathrm{A}$ \\
\hline Salmonella abony & - & - & - & - & - & - & - & - & $\mathrm{N} / \mathrm{A}$ & $\mathrm{N} / \mathrm{A}$ \\
\hline Escherichia coli ATCC8739 & - & - & - & - & - & - & - & - & $\mathrm{N} / \mathrm{A}$ & $\mathrm{N} / \mathrm{A}$ \\
\hline Bacillus subtilis ATCC6633 & - & - & - & - & - & - & - & - & $\mathrm{N} / \mathrm{A}$ & $\mathrm{N} / \mathrm{A}$ \\
\hline Bacillus subtilis 46/H1 & - & - & - & - & - & - & - & - & $\mathrm{N} / \mathrm{A}$ & $\mathrm{N} / \mathrm{A}$ \\
\hline Bacillus methylotrophicus BM47 & - & + & + & - & - & - & - & - & $\mathrm{N} / \mathrm{A}$ & $\mathrm{N} / \mathrm{A}$ \\
\hline
\end{tabular}

Legend: *low antimicrobial activity, ** moderate antimicrobial activity; "“" no inhibition, "+" - stimulation of growth, N/A - not applied

sumers and some are able to grow on multicarbon compounds $^{26}$. Moreover, Bacillus methylotrophicus BM47 was reported to possess high antifungal activity against phytopathogens Fusarium oxysporum and Aspergillus flavus ${ }^{27}$. The stimulating activity of octa-O-acetylsucrose over Bacillus methylotrophicus BM47 could be successfully used in agriculture for plant protection against fungal phytopathogens. Influence of structure on the antimicrobial activity of octa- $O$-acetylsucrose was studied. It was confirmed that short acetyl moiety of sucrose esters is unable to affect the growth of Gram-positive and Gram-negative bacteria in comparison with sucrose laurinate and undecylate ester that possess strong antimicrobial activity $3,5,23,24,28$.

Because of its antifungal activity, proved by the experiments, octa- $O$-acetylsucrose could be successfully applied in agriculture for development of new formula in prospective crop and plant protection, for example, environmentally friendly fungicide based on sucrose esters. The promising foaming and emulsifying ability of octa- $O$-acetylsucrose offers an adequate solution to problems related to treatment and adhesion over the root or leaf surfaces. Additional investigation may be required concerning this field of application, and it could be the object of further experimental work.

\section{Conclusions}

A "green" method for synthesis of the octa- $O$-acetylsucrose by ultrasound-assisted esterification in the absence of a solvent by using acetic anhydride and sodium acetate as a catalyst has been demonstrated. The structure of the resulting ester has been elucidated by FT-IR and NMR spectroscopy, and a study of sucrose octaacetate as a surface active agent with HLB 9-10 was carried out. The obtained results revealed promising foamability, foaming stability of octa- $O$-acetylsucrose, and its use as antifungal substance against Penicillium $s p$. These properties of octa- $O$-acetylsucrose and its ability to stabilize oil-in-water emulsions could find potential application in beverages, drug delivery matrix, agriculture, and cosmetic products. 


\section{References}

1. Megahed, M., Preparation of sucrose fatty acid esters as food emulsifiers and evaluation of their surface active and emulsion properties, Grasas y Aceites 50 (1999) 280. doi: https://doi.org/10.3989/gya.1999.v50.i4.668

2. Zhang, X., Song, F., Taxipalati, M., Wei, W., Feng, F., Comparative study of surface-active properties and antimicrobial activities of disaccharide monoesters, PLoS ONE 9 (2014) 1. doi: https://doi.org/10.1371/journal.pone.0114845

3. Matev, G., Petkova, N., Vrancheva R., Ivanov, I., Pavlov, A., Denev, $P$., Synthesis, characterization and application of sucroesters as antimicrobial agents, University of Plovdiv "Paisii Hilendarski” Bulgaria, Scientific papers 39 (5) (2014) 17.

4. Petkova, N., Vassilev, D., Grudeva, R., Koleva, M., Denev, $P$., Ultrasound-assisted synthesis of undecylenoyl sucrose esters, International Scientific Conference "Unitech 2015" 20 - 21 November 2015 Gabrovo, University Publishing House "V. Aprilov" - Gabrovo, 2015, 517.

5. Vassilev, D., Petkova, N., Koleva, M., Denev, P., Ultrasoundassisted synthesis of sucrose and fructooligosaccharides esters as bio-plasticizers, J. Renew. Mater. 4 (2016) 24. doi: https://doi.org/10.7569/JRM.2015.634125

6. Yamauchi, N., Tokuhara, Y., Ohyama, Y., Shigyo, M., Inhibitory effect of sucrose laurate esters on degreening in Citrus nagato-yuzukichi fruit during storage, Postharv. Biol. Technol. 47 (2008) 333.

doi: https://doi.org/10.1016/j.postharvbio.2007.08.003

7. CFR: 40 CFR 180.910, Inert reassessment: sucrose octaacetate (CAS reg. no. 126-14-7). Office of Prevention, Pesticides, And Toxic Substances, United States Environmental Protection Agency Washington, D.C. 20460, (2005) 1.

8. Li, Sh., Song, Z., Liu, Zh., Bai, S., Characterization and insecticidal activity of sucrose octanoates, Agron. Sustain. Dev. 28 (2008) 239.

doi: https://doi.org/10.1051/agro:2007037

9. Song, Zi-j., Shu-jun, L., Chen, X., Li-mei, L., Song, Zh., Synthesis of insecticidal sucrose esters, For. Stud. China 8 (2006) 26.

doi: https://doi.org/10.1007/s11632-006-0019-2

10. Chortyk, O., Stanley, J., Quincy, T., Characterisation of insecticidal sugar esters of Petunia, J. Agric. Food Chem. 45 (1997) 270. doi: https://doi.org/10.1021/jf960322f

11. Singh, A., Singh, A., Begum, A., Sahai, M., Two acyl sucroses from Petunia nyctaginiflora, Phytoch. 63 (2003) 485. doi: https://doi.org/10.1016/S0031-9422(03)00162-6

12. Steverink-de Zoete, M., Kneepkens, M., de Waard, P., van Oosterom, M., Slaghek, T., Gotlieb, K., Enzymatic synthesis and NMR studies of acylated sucrose acetates, Green Chem. 1 (1999) 153. doi: https://doi.org/10.1039/a901381d

13. Patil, B., Babu, $V$., A rapid and convenient synthesis of $\alpha$ and $\beta$ forms of acetylated derivatives of sugars under microwave irradiation, Ind. J. Chem., Section B: Organ. Chem. Med. Chem. 43B (2004) 1288.

14. Peng, X., Yang, J. Y., Kováč, P., Observations on the preparation of $\beta$-lactose octaacetate, J. Carbohyd. Chem. 31 (2012) 711 .

doi: https://doi.org/10.1080/07328303.2012.739230
15. Matin, M., Bhuiyan, M., Afrin, A., Debnath, D., Comparative antimicrobial activities of some monosaccharide and disaccharide acetates, J. Sci. Res. 5 (2013) 515. doi: https://doi.org/10.3329/jsr.v5i3.15695

16. Huang, D., Jiang, X., Improved synthesis of sucrose fatty acid monoesters under ultrasonic irradiation, Ultrason. Sonochem. 17 (2010) 352. doi: https://doi.org/10.1016/j.ultsonch.2009.08.009

17. Griffin, $W$. C., Classification of surface-active agents by "HLB", J. Soc. Cosmet. Chem. 1 (1949) 311.

18. Murdzheva, D., Vasileva, Iv., Petkova, N., Ivanov, I., Todorova, M., Denev, P., Physicochemical properties of new alginic acids derivatives, Indust. Technol. 3 (2016) 59.

19. Vlaseva, R., Ivanova, M., Petkova, N., Denev P., Stoyanova A., Schreiner, M., Obtaining stable food emulsions between milk and corn oil, Bulg. J. Agric. Sci. 20 (2014) 1085.

20. Tumbarski, Y., Petkova, N., Ivanov I., Polyphenolic content, antioxidant activity and antimicrobial properties of leaf extracts from dandelion (Taraxacum officinale), Indust. Technol. 3 (1) (2016) 141.

21. Petkova, N., Gencheva, G., Tumbarski, Y., Vasslev, D., Koleva, M., Denev, P., Ultrasound-assisted synthesis of inulin esters with potential antimicrobial activity, Unitech-2016, International Scientific Conference, 18 - 19 November 2016, Gabrovo, I, 2016, 408.

22. Ferreira, M., Benringer, R., Jost, R., Instrumental method for characterizing protein foams, J. Food Sci. 60 (1995) 90. doi: https://doi.org/10.1111/j.1365-2621.1995.tb05613.x

23. Conley, A., Kabara, J., Antimicrobial action of esters of polyhydric alcohols, Antimicrob. Agents Chemother. 4 (5) (1973) 501. doi: https://doi.org/10.1128/AAC.4.5.501

24. Kabara, J., Marshall, D., Medium-chain fatty acids and esters, in Davidson, M. P., Sofos, J. N., Branen, A. L. (Eds.), Antimicrobials in Food, 3 ed., CRC Press, Taylor \& Francis Group, New York, 2005, pp 328-336.

25. Li, Y., Geng, X., Ji, P., Pan, Ch., Wei, Sh., Isolation and evaluation of a Bacillus methylotrophicus strain for control of corn stalk rot, Biocontrol. Sci. Technol. 26 (2016) 727. doi: https://doi.org/10.1080/09583157.2016.1144047

26. Madhaiyan, M., Poonguzhali, S., Kwon, S., Sa, T. M., Bacillus methylotrophicus sp. nov., a methanolutilizing, plant-growth-promoting bacterium isolated from rice rhizosphere soil, Int. J. Syst. Evol. Microbiol. 60 (2010) 2490. doi: https://doi.org/10.1099/ijs.0.015487-0

27. Tumbarski, Y., Petkov, E., Denkova Z., Study on the influence of the cultural conditions and the composition of the culture medium on the antimicrobial activity of Bacillus methylotrophicus BM 47 against some fungal phytopathogens, J. Glob. Biosci. 4 (8) (2015) 2990.

28. Ferrer, M., Soliveri, J., Plou, F., Lopez-Cortes, N., Reyes-Duarte, D., Christensen, M., Copa-Patiño, J., Ballesteros, $A$., Synthesis of sugar esters in solvent mixtures by lipases from Thermomyces lanuginosus and Candida antarctica $\mathrm{B}$ and their antimicrobial properties, Enzyme Microb. Technol. 36 (4) (2005) 391. doi: https://doi.org/10.1016/j.enzmictec.2004.02.009 